\title{
Meningkatkan Motivasi dan Prestasi Belajar Matematika Melalui Pembelajaran Tutor Sebaya Kompetensi Dasar Operasi Hitung Pecahan Dalam Pemecahan Masalah Pada Kelas VI SD Inpres 35 Kabupaten Sorong Tahun Pelajaran 2015/2016
}

\author{
Imas Eni \\ SD Inpres 35 Kabupaten Sorong \\ Email: imaseni@ymail.com
}

\begin{abstract}
This research is a classroom action research which consists of two cycles. Every cycle consists of planning, action, observation and reflection. This research aims at improving students' motivation and learning achievement in Math through peer tutor learning at the basic competency of fraction in problem solving at the sixth grade students of SD Inpres 35 Sorong Regency academic year 2015/2016. The data collection was done by using test and observation. The data was analyzed by using quantitative descriptive analysis. The result of the research showed there is improvement on students' Mathematic learning achievement especially in the basic competency of fraction in problem solving after the application of peer tutor learning. This was proved by the improvement of the number of students who have reached the minimum score criteria (KKM) in every cycle and class activities percentage. At the beginning, there were only $57 \%$ of students who passed and $43 \%$ students who did not pass the test. The average score was 64 . In cycle I, there were $71 \%$ students who passed and $29 \%$ students who did not pass the test. The average score increased to 69. On the cycle I, the result had not shown significant improvement so the writer conducted cycle II. At the end of cycle II, the average score was 81 and the number of students who pass the test was $100 \%$.
\end{abstract}

Keywords: learning achievement, peer tutor, fraction calculation operation

\begin{abstract}
Abstrak: Penelitian ini adalah penelitian tindakan kelas yang dilakukan dengan langkah-langkah perencanaan, pelaksanaan tindakan, observasi, dan refleksi yang bertujuan untuk meningkatkan motivasi dan prestasi belajar matematika melalui pembelajaran tutor sebaya kompetensi dasar operasi hitung pecahan dalam pemecahan masalah pada Kelas VI SD Inpres 35 Kabupaten Sorong Tahun Pelajaran 2015/2016. Penelitian dilakukan 2 siklus, tiap siklus terdiri dari 2 pertemuan. Pengumpulan data dalam penelitian ini menggunakan tes dan observasi. Teknik analisis data berupa analisis deskriptif kuantitatif. Hasil penelitian ini menunjukkan bahwa terjadi peningkatan hasil belajar matematika khususnya kompetensi dasar operasi hitung pecahan dalam pemecahan masalah melalui pembelajaran tutor sebaya. Hal itu ditandai dengan meningkatnya jumlah siswa yang mencapai KKM dalam tiap siklus dan persentase aktivitas kelas. Terbukti dari kondisi awal dengan nilai rata-rata awal atau pra siklus sebesar 64 yang tuntas $57 \%$ dan yang tidak tuntas $43 \%$. Siklus I nilai rata - rata 69 yang tuntas $71 \%$ dan yang belum tuntas $29 \%$. Pada siklus I belum mencapai ketuntasan karena tuntas tuntas jika hasilnya $85 \%$. Sehingga diadakan siklus II. Pada siklus II mengalami peningkatan dengan nilai rata-rata menjadi 81 dan mencapai ketuntasan $100 \%$.
\end{abstract}

Kata kunci: prestasi belajar,tutor sebaya, operasi hitung pecahan

\section{Pendahuluan}

Salah satu indikator mutu pendidikan adalah jika nilai prestasi siswa sesuai KKM dan rata-rata kelas menunjukkan peningkatan. Baik tidaknya prestasi siswa ditentukan oleh beberapa faktor. Salah satu faktor yang paling dominan adalah guru. Dominasi guru dalam upaya peningkatan prestasi siswa terjadi dalam proses pembelajaran di dalam kelas. Proses 
pembelajaran yang kurang menarik dan kurang variatif dapat menjadikan proses pembelajaran itu menjenuhkan. Akibatnya prestasi siswa tidak dapat menjadikan proses pembelajaran itu menjenuhkan. Akibatnya prestasi siswa tidak dapat ditingkatkan. Sebaliknya prestasi siswa dapat ditingkatkan jika ada upaya mengubah proses pembelajaran. Yakni dari proses pembelajaran yang menjenuhkan diubah menjadi proses pembelajaran yang menarik dan bahkan mungkin yang mengasikkan.

Selama ini upaya untuk meningkatkan mutu pendidikan belum menunjukkan peningkatan yang berarti, bahkan dapat dikatakan masih jalan di tempat. Dari pengamatan peneliti, yang menjadikan kendala pada masalah di atas salah satunya adalah pada pelajaran matematika. Kenyataannya yang ada di lapangan menunjukkan bahwa dari semua mata pelajaran di SD Inpres 35 Kabupaten Sorong, matematika merupakan pelajaran yang nilai rata-rata kelasnya paling rendah. Betapa tidak, prestasi itu dari tahun ke tahun hanya pada kisaran 54 sampai 57. Upaya peningkatan mutunya pun masih terfokus pada upaya peningkatan prestasi pada mata pelajaran matematika. Sebagian siswa juga masih beranggapan bahwa mata pelajaran matematika adalah pelajaran yang paling sulit.

Dari kondisi tersebut di atas dapat dirasakan bahwa pelajaran matematikan di SD tempat peneliti bekerja belum menunjukkan hasil yang diharapkan. Yakni matematika yang dapat menjadikan siswa berpikir secara logis dan rasional, bersikap kritis, cermat, dan efisien, serta mampu memecahkan masalah sesuai dengan jenjang pendidikan di SD.

Upaya guru dalam proses pembelajaran belum mampu meningkatkan aspek kemampuan dan aktivitas siswa. Lewat penelitian ini peneliti tertarik pada upaya yang dapat menumbuhkembangkan aspek kemampuan dan aktivitas siswa. Pembelajaran tutor sebaya dalam kelompok-kelompok belajar itulah yang ingin dilakukan dalam penelitiannya untuk menciptakan kondisi belajar pada pelajaran matematika yang menyenangkan bahkan mengasikkan. Lewat pembelajaran tutor sebaya ini penelitian bertujuan ingin menepis anggapan yang keliru terhadap mata pelajaran matematika seperti tersebut di atas.

Berdasarkan latar belakang masalah, peneliti melakukan penelitian tindakan kelas untuk meningkatkan motivasi dan prestasi belajar matematika kelas VI SD Inpres 35 Kabupaten Sorong semester 2 melalui pembelajaran tutor sebaya pada kompetesi dasar operasi hitung pecahan dalam pemecahan masalah Tahun Pelajaran 2015/2016.

\section{Metode Penelitian}

\subsection{Subjek Penelitian}

Subjek penelitian adalah siswa kelas VI SD Inpres 35 Kabupaten Sorong Tahun Pelajaran 2015/2016 yang berjumlah 14 siswa terdiri dari 9 siswa laki-laki 5 siswa perempuan. 


\subsection{Lokasi dan Waktu Penelitian}

Penelitian dilaksanakan di SD Inpres 35 Kabupaten Sorong, yang merupakan sekolah tempat peneliti mengajar beralamat di jalan Poros Makotyamsa Distrik Mayamuk Kabupaten Sorong. Penelitian dilaksanakan mulai tanggal 11 Januari - 4 Februari 2016.

\subsection{Prosedur Penelitian}

Penelitian ini merupakan penelitian tindakan kelas yang ditandai dengan adanya siklus, adapun dalam penelitian ini terdiri atas 2 siklus. Setiap siklus terdiri atas perencanaan, pelaksanaan, observasi dan refleksi.

a. Siklus I

1) Perencanaan (planning), terdiri atas kegiatan: a) Menyusun rencana pelaksanaan pembelajaran, b) Kisi-kisi penyusunan rencana pembelajaran, c) Menyiapkan soal ulangan harian, d) Menyiapkan jawaban ulangan, e) Menyiapkan lembar pengamatan, f) Menyiapkan lembar pengamatan penilaian ranah efektif, g) Menyiapkan rubric lembar ranah efektif, h) Daftar hadir, dan i) Minat terhadap pelajaran matematika

2) Pelaksanaan

Sesuai dengan langkah-langkah pada rencana pelaksanaan pembelajaran.

3) Observasi (pengamatan)

4) Refleksi

Yaitu menyimpulkan pelaksanaan hasil tindakan pada siklus II.

b. Siklus II

1) Perencanaan (planning), terdiri atas kegiatan: a) Menyusun rencana pelaksanaan pembelajaran, b) Menyiapkan soal ulangan harian, c) Menyiapkan jawaban ulangan, d) Menyiapkan lembar pengamatan, e) Menyiapkan lembar pengamatan penilaian ranah efektif, dan f) Menyiapkan rubik lembar ranah efektif

2) Pelaksanaan

Sesuai dengan langkah-langkah pada rencana pelaksanaan pembelajaran.

3) Observasi (pengamatan)

4) Refleksi, yaitu menyimpulkan pelaksanaan hasil tindakan pada siklus II.

\subsection{Teknik Pengumpulan Data}

Data yang diambil berasal dari hasil tes dan non tes antara siklus I ke siklus berikutnya. Dari perubahan hasil tes, jika menunjukkan kenaikan positif secara signifikan berarti terjadi peningkatan pembelajaran. Tetapi jika sebaliknya, maka perlu refleksi dan perbaikan pelaksanaan model pembelajaran yang diterapkan antar siklus selanjutnya. Sedangkan perubahan hasil non tes 
baik dari wawancara, angket maupun jurnal, diungkap apa adanya sesuai hasil yang telah terkumpul sebagai perbandingan antara siklus I dengan siklus berikutnya.

Sementara indikator kinerja dari penelitian tindakan kelas dikatakan berhasil jika 85\% siswa kelas VI SD Inpres 35 Kabupaten Sorong bisa tuntas. Kriteria ketuntasan 68.

\section{Hasil Penelitian Dan Pembahasan}

\subsection{Hasil Penelitian}

\subsubsection{Siklus I}

a. Data Pengamatan (Observasi)

Diagram 1 Hasil Pengamatan Siswa Pada Siklus I

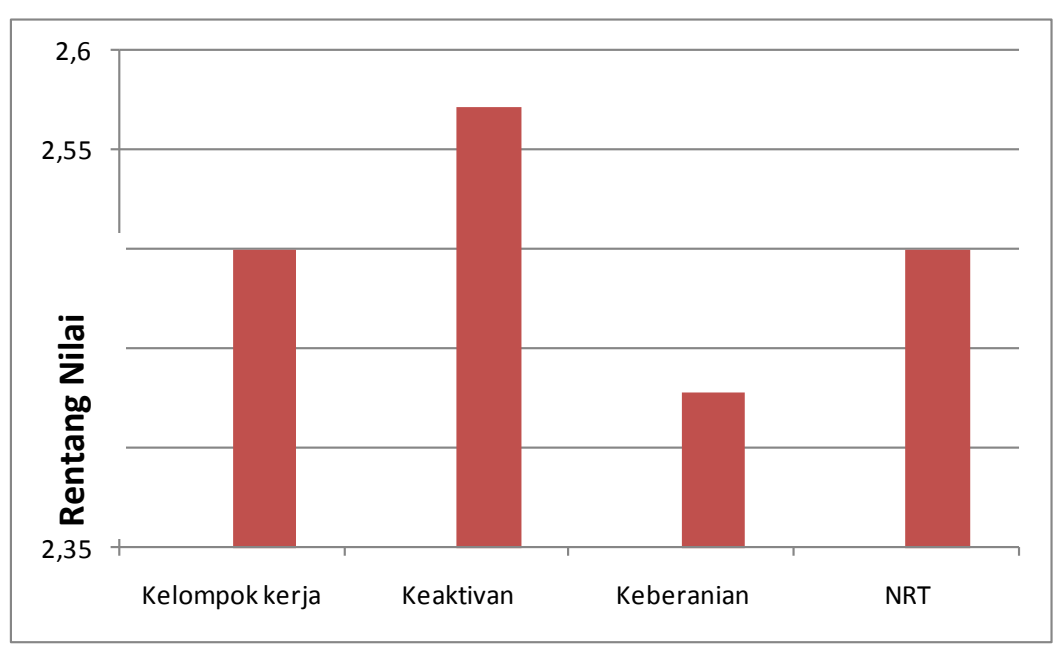

b. Data Hasil Belajar Siklus I

\section{Aspek}

Diagram 2. Hasil Tes Formatif Pada Siklus I

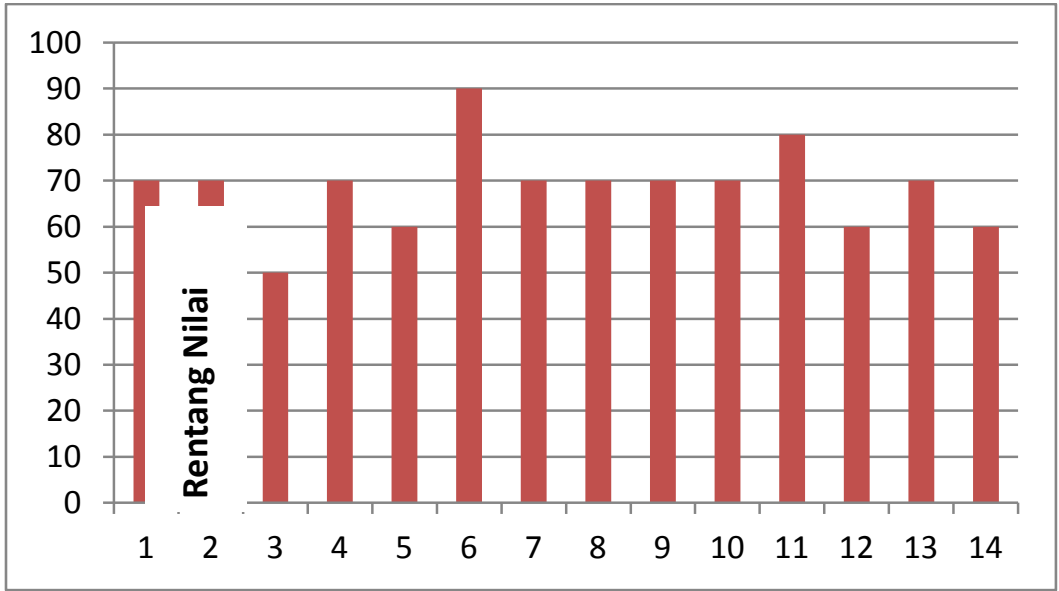

No. Urut Siswa 
c. Kegiatan Belajar Mengajar Siklus I

Tabel 1. Hasil Instrumen Pengamatan Kegiatan Pembelajaran

\begin{tabular}{clcc}
\hline No. & \multicolumn{1}{c}{ Bentuk Kegiatan } & Nilai Rata-rata & Keterangan \\
\hline A. & Aktivitas Siswa & 69 & Baik \\
B. & Kinerja Guru & 73 & Baik \\
C. & Sarana Pembelajaran & 60 & Baik \\
\hline
\end{tabular}

\subsubsection{Siklus II}

a. Data Pengamatan (Observasi)

Diagram 3. Hasil Pengamatan Siswa Pada Siklus II

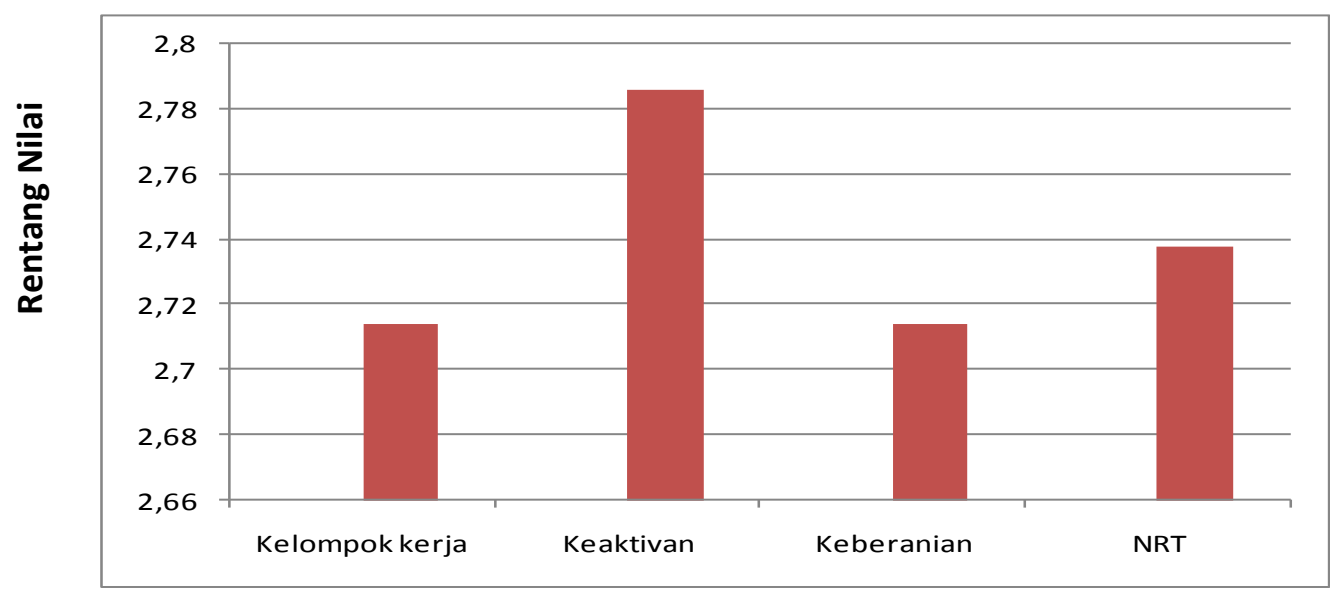

b. Data Hasil Belajar Siklus II

\section{Aspek}

Diagram 4. Hasil Tes Formatif Pada Siklus II

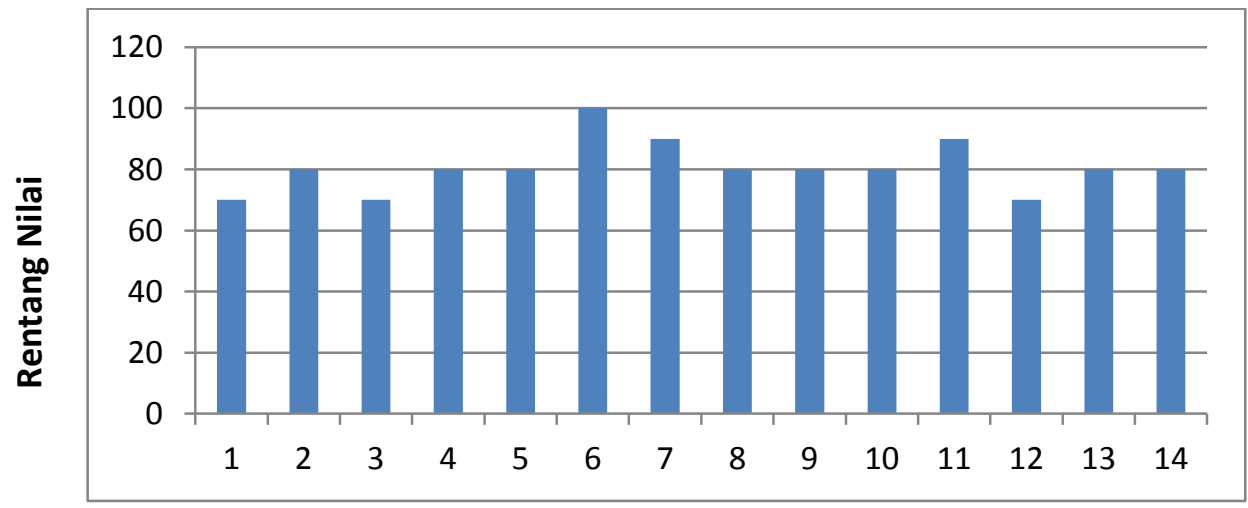

No. Urut Siswa 
c. Data Kegiatan Belajar Mengajar Siklus II

Tabel 2. Hasil Instrumen Pengamatan Kegiatan Pembelajaran

\begin{tabular}{clcc}
\hline No. & \multicolumn{1}{c}{ Bentuk Kegiatan } & Nilai Rata-rata & Keterangan \\
\hline A. & Aktivitas Siswa & 75 & Baik \\
B. & Kinerja Guru & 76 & Baik \\
C. & Sarana Pembelajaran & 70 & Baik \\
\hline
\end{tabular}

\subsection{Pembahasan}

\subsubsection{Siklus I}

Adapun penilaian hasil pengamatan pada siklus I dengan 3 aspek kerja kelompok, aspek keaktifan, aspek keberanian adalah $2,5+2,57+2,43=7,5$. Jadi rata-rata nilai ketiga aspek tersebut 2,5, berarti secara keseluruhan hasil pengamatan pada siklus I adalah baik. Berdasarkan tabel 3 di atas bahwa hasil evaluasi pada pembelajaran matematika dengan metode tutor sebaya pada siswa kelas VI sudah mencapai ketuntasan klasikal, karena 11 siswa telah tuntas belajar. Adapun rata-rata nilai ada kenaikan dari kondisi awal 64,29 menjadi 68,57. Namun hal ini belum mencapai kenaikan optimal. Oleh karena itu, perlu tindakan selanjutnya.

\subsubsection{Siklus II}

Adapun penilaian hasil pengamatan pada siklus II dengan 3 aspek kerja kelompok, aspek keaktifan, aspek keberanian adalah $2,71+2,79+2,71=8,21$. Jadi rata-rata ketiga aspek tersebut $=2,74$, berarti secara keseluruhan hasil pengamatan pada siklus II adalah baik. Berdasarkan tabel 6 di atas: bahwa hasil evaluasi pada pembelajaran matematika dengan metode tutor sebaya pada siswa kelas VI semester I SD Inpres 35 Kabupaten Sorong sudah mencapai ketuntasan klasikal, karena 100\% siswa telah tuntas belajar. Adapun rata-rata nilai adalah 80,71 dengan rata-rata tersebut berarti ada kenaikan dari siklus I rata-rata nilai 68,57 menjadi 80,71. Nilai rata-rata ini telah memenuhi standar ketuntasan belajar klasikal yaitu $85 \%$.

Diagram 5. Perbandingan Hasil Tes Formatif Pra Siklus, Siklus I, dan Siklus II.

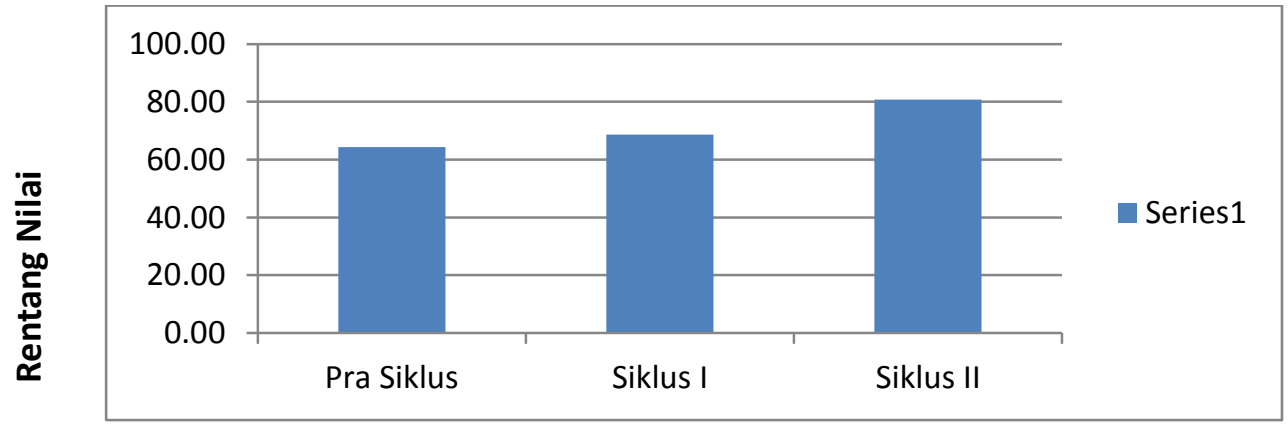




\subsubsection{Pembahasan Antar Siklus}

Prestasi belajar matematika melalui pembelajaran tutor sebaya pada kompetesi dasar operasi hitung pecahan dalam pemecahan masalah yang dilakukan peneliti kepada 14 siswa kelas VI SD Inpres 35 Kabupaten Sorong sebelum adanya perbaikan pembelajaran (kondisi awal) menunjukkan bahwa masih banyak siswa yang kurang memahami, kurang mengerti dan peran serta mereka dalam pembelajaran masih pasif. Atas dasar hal tersebut, peneliti melakukan perbaikan pembelajaran melalui 2 siklus yang setiap siklusnya terdiri dari 4 (empat) tahapan, yaitu perencanaan, pelaksanaan, observasi dan refleksi.

Hasil dari pembelajaran siklus I menunjukkan adanya peningkatan prestasi belajar siswa. Hal itu dapat dilihat dari adanya 10 siswa yang memperoleh nilai tuntas KKM dengan rata-rata nilai adalah 68,57. Rata-rata tersebut telah mengalami peningkatan yang cukup baik jika dibandingkan dengan kondisi awalnya hanya 8 siswa yang memperoleh nilai tuntas KKM dengan nilai rata-rata 64,29. Nilai rata-rata sebesar 68,57 dengan prosentase ketuntasan belajar $79 \%$ belum mencapai ketuntasan belajar klasikal sehingga diperlukan tindakan selanjutnya yakni siklus II.

Pada pembelajaran siklus II peneliti memfokuskan pada perbaikan dalam pemecahan soal-soal dan tugas secara berkelompok dengan jumlah siswa per kelompok lebih kecil yakni 4 orang sehingga antara anggota kelompok tersebut mampu berinteraksi secara baik dalam mengerjakan tugas yang diberikan dan setiap kelompok mempresentasikan hasilnya.

Sebagai upaya untuk meningkatkan keaktifan belajar siswa pembelajaran pada siklus II ini indikator yang digunakan adalah peran serta siswa dalam melaksanakan proses pembelajaran. Dengan pemberian penguatan yang positif dari guru, semangat motivasi antar teman sehingga peran serta mereka dapat meningkat. Hal ini dapat dilihat dari keaktifan siswa dalam mengerjakan soal baik dari guru maupun dari LKS di papan tulis dan keberanian para siswa dalam mengacungkan jari untuk menjawab pertanyaan secara lantang tanpa ragu-ragu dan para siswa berlomba-lomba untuk menjadi kelompok terbaik yang mampu memecahkan soal-soal matematika pada kompetensi dasar operasi hitung pecahan dalam pemecahan masalah.

Dari hal tersebut di atas terlihat hasil tes formatif dari 14 siswa telah memperoleh nilai ketuntasan belajar dengan nilai rata-rata kelas 80,71.

\section{Kesimpulan dan Saran}

\subsection{Kesimpulan}

Dari hasil penelitian yang dilakukan ada beberapa kesimpulan, yaitu : 
1) Kemampuan belajar seorang siswa dalam memahami suatu konsep pembelajaran matematika dengan kompetesi dasar operasi hitung pecahan dalam pemecahan masalah dapat diatasi dengan menggunakan metode tutor sebaya.

2) Metode tutor sebaya dalam pembelajaran matematika kompetesi dasar operasi hitung pecahan dalam pemecahan masalah sangat efektif, karena hal yang tidak dapat dijelaskan oleh guru kadang dapat diterangkan oleh teman sebaya secara sederhana dan dengan bahasa yang lebih mudah dimengerti. Hal ini dapat dilihat dari data hasil prestasi belajar siswa antar siklus melalui tes formatif yaitu: Untuk nilai rata-rata kelas dari konsi awal 64,29 mejadi 68,57 pada siklus I dan 80,71 pada siklus II. Pada kondisi awal murid yang tuntas belajar 8 orang (57\%), siklus I 10 orang (71\%) dan siklus II 14 orang (100\%).

\subsection{Saran}

Berdasarkan kesimpulan tersebut di atas, ada beberapa saran yang perlu peneliti sampaikan, yaitu sebagai berikut :

1) Metode tutor sebaya sebenarnya sangat efektif dalam pembelajaran matematika kompetensi dasar operasi hitung pecahan dalam pemecahan masalah, karena siswa dapat belajar sesuai dengan tingkat pemahaman dan penalarannya.

2) Diharapkan guru mampu mengimplementasikan proses pembelajaran yang menitikberatkan pada kegiatan yang mampu membuat siswa tidak hanya belajar deduktif tetapi juga berfikir induktif.

\section{Daftar Pustaka}

Aria, Djalil. 1997. Teori-teori Perkembangan. Surabaya : Institut Keguruan dan Ilmu Pendidikan. Badan Standar Nasional Pendidikan (BSNP). 2006. Standar Isi dan Standar Kompetensi Lulusan Tingkat Sekolah dasar dan Madrasah Ibtidaiyah (Permen Mendiknas No. 22, No. 23, dan No. 24 Tahun 2006). Jakarta: PT. Binatama Raya.

Cholik dan Sugijono. 2002. Matematika untuk SD Kelas VI. Jakarta: Erlangga.

Sukandar, Siti M. Amin. 1995. Pembelajaran Matematika SD. Semarang: IKIP Negeri Semarang. Suprayekti. 2003. Strategi Pembelajaran Matematika Kontemporer. Bandung: UPI.

Surya, HM.1997. Pengajaran Remedial. Jakarta: Depdikbud.

Suyitno, Amin. 2004. Dasar-Dasar dan Proses Pembelajaran Matematika. Semarang: FMIPA UNNES. 